\title{
Cardiovascular, ophthalmologic and otolaryngologic medical device innovations - Progress report 2021 from the Twenty20 consortium RESPONSE
}

\begin{abstract}
The coordinated research project "RESPONSE Partnership for Innovation in Implant Technology", which is one of ten BMBF-funded research consortia within the program "Twenty20 - Partnership for Innovation", is active in the field of medical device innovation. The consortium is currently in the process of unfolding its transfer phase. This involves a portfolio of key innovations for novel medical devices, technologies and processes. Also, RESPONSE is aiming at participative technology development, integrating perspectives of patients, developers, as well as systems and innovation researchers. Particular challenges are arising from the current re-prioritization and re-scheduling of project roadmaps in order to manage and alleviate the effects of the corona crisis.
\end{abstract}

Keywords: implant, combination product, stent, heart valve, glaucoma, Eustachian tube, cochlea, Fallopian tube, pancreas

https://doi.org/10.1515/cdbme-2021-2181

\section{Background}

Since its start in 2014, the coordinated research project "RESPONSE - Partnership for Innovation in Implant Technology", which is one of ten BMBF-funded research consortia within the program "Twenty20 - Partnership for Innovation", has been active in the field of medical device innovation. For this purpose, a network of 33 partners from science, medicine and industry has been established to jointly

\footnotetext{
*Corresponding author: Niels Grabow: Institute for Biomedical Engineering, University Medical Center Rostock, FriedrichBarnewitz-Str. 4, 18119 Rostock, e-mail: niels.grabow@unirostock.de

Volkmar Senz: Institute for Biomedical Engineering, University Medical Center Rostock, Germany

Klaus-Peter Schmitz: Institute for Biomedical Engineering, University Medical Center Rostock, and Institute for ImplantTechnology and Biomaterials e.V., Warnemuende, Germany
}

foster contributions to the field of cardiovascular, ophthalmologic and otolaryngologic applications. Most recently, gynecologic and gastroenterologic device-related topics have been integrated.

\section{Current Situation}

RESPONSE is currently in the process of unfolding its transfer phase, with an emphasis on ex vivo and preclinical in vivo testing of novel medical device concepts $[1,2]$. This involves a portfolio of medical device innovations, technologies and processes, aiming beyond the completion of the funding period in 2021/22: (i) covered stents and absorbable scaffolds, (ii) electrospun nanofibrous nonwovens for transcatheter heart valves for cardiovascular medicine, (iii) glaucoma microstents and (iv) Eustachian tube stents for ophthalmic and otolaryngologic application, respectively (Figure 1).

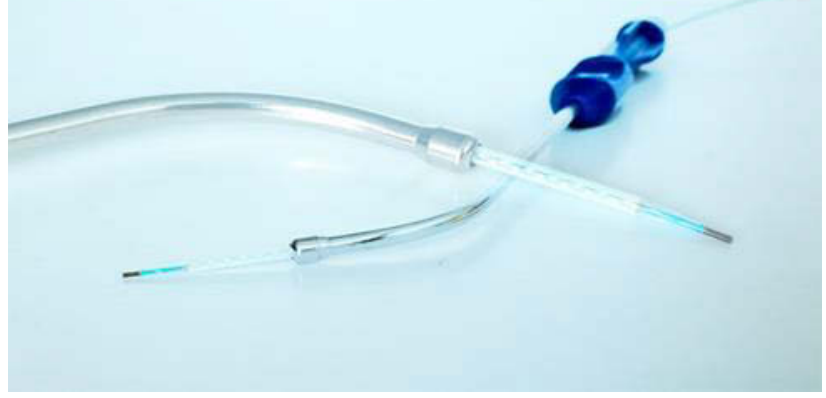

Figure 1: Absorbable polymeric Eustachian tube stent system.

Potentials for synergies are being used for (v) Fallopian tube and (vi) pancreas stent applications. Based on extensive studies of absorbable polymeric implant materials [3, 4] and hydrogels $[5,6]$, technological innovations comprise drug delivery systems $[7,8]$ and nanofibrous nonwoven materials for responsive functionalized implants [9-11]. In silico methods shall enable novel device characteristics, such as reduced thrombotic potential of cardiovascular implants [12] 
as well as improved quality assurance [13]. Smart implant concepts are being pursued towards reduced implantation trauma [14], as well as novel diagnostic and therapeutic functions. Also, RESPONSE is aiming at participative technology development, integrating perspectives of patients, developers and medical professionals, as well as systems and innovation researchers $[15,16]$.

\section{Prospect}

RESPONSE will continue its efforts in tackling the adverse effects of the corona pandemic on the collaborative work within a close network of clinical, non-clinical and industry partners. Apart from immediate lockdown effects on the progression of practical R\&D work, particular challenges are arising from the necessity of re-prioritization and rescheduling of joint project roadmaps. However, while short term clinical shutdown effects may have a transient effect on the market participants, mid and long term market demands remain warranted.

\section{Author Statement}

Research funding: Financial support by the German Federal Ministry of Education and Research (BMBF program: Twenty20 - Partnership for Innovation) for the project "RESPONSE - Partnership for Innovation in Implant Technology" is gratefully acknowledged. Conflict of interest: Authors state no conflict of interest.

\section{References}

[1] Schümann K, Wilfling T, Paasche G, Schuon R, Tautorat C, Schmitz KP, Lenarz T, Grabow N. Polymeric stents for the Eustachian tube: development and human cadaver study Curr Dir Biomed Eng. 2020;6(3):213-6. doi: 10.1515/cdbme2020-3054

[2] Öner A, Moerke C, Wolff A, Kischkel S, Schmidt W, Grabow $\mathrm{N}$, Ince $\mathrm{H}$. A preclinical animal model for evaluating the sealing capacity of covered stent grafts in acute vessel perforation. Eur J Med Res. 2020;25(1):28. doi: 10.1186/s40001-020-00429-y

[3] Arbeiter D, Eickner T, Oschatz S, Reske T, Specht O, Teske M, Senz V, Schmitz KP, Grabow N. Physico chemical and phase separation characterization of high molecular PLLA blended with low molecular PCL obtained from solvent cast processes. Mater Res Express. 2020;7:095302. doi: 10.1088/2053-1591/abb2c9

[4] Strohbach A, Maess F, Wulf K, Petersen S, Grabow N, Schmitz KP, Felix SB, Busch R. The Role of Biodegradable
Poly-(L-lactide)-Based Polymers in Blood Cell Activation and Platelet-Monocyte Interaction. Int J Mol Sci. 2021;22(12):6340. doi: 10.3390/ijms22126340

[5] Claus J, Brietzke A, Lehnert C, Oschatz S, Grabow N, Kragl U. Swelling characteristics and biocompatibility of ionic liquid based hydrogels for biomedical applications. PLoS One. 2020;15(4):e0231421. doi: 10.1371/journal.pone.0231421

[6] Sievers J, Sperlich K, Stahnke T, Kreiner C, Eickner T, Martin H, Guthoff RF, Schünemann M, Bohn S, Stachs O. Determination of hydrogel swelling factors by two established and a novel non - contact continuous method. J Appl Polym Sci. 2021;138:50326. doi: 10.1002/app.50326

[7] Arbeiter D, Reske T, Teske M, Bajer D, Senz V, Schmitz KP, Grabow N, Oschatz S. Influence of Drug Incorporation on the Physico-Chemical Properties of Poly(I-Lactide) Implant Coating Matrices-A Systematic Study. Polymers (Basel). 2021;13(2):292. doi: 10.3390/polym13020292

[8] Claus J, Eickner T, Grabow N, Kragl U, Oschatz S. Ion Exchange Controlled Drug Release from Polymerized lonic Liquids. Macromol Biosci. 2020;20(9):e2000152. doi: 10.1002/mabi.202000152

[9] Wulf K, Arbeiter D, Matschegewski C, Teske M, Huling J, Schmitz KP, Grabow N, Kohse S. Smart releasing electrospun nanofibers-poly: L.lactide fibers as dual drug delivery system for biomedical application. Biomed Mater. 2020;16(1):015022. doi: 10.1088/1748-605X/abbec8

[10] Oschatz ST, Illner S, Ortelt J, Arbeiter D, Teske M, Müller H, Grabow N, Momma C, Schmitz KP. Adaptive chemical postprocessing of nonwovens for cardiovascular applications. WO2021110559A1, 2021

[11] Kohse S, Schümann K, Grabow N, Bajer D, Schmitz KP, Großmann S, Müller H, Momma C. Verfahren zur Herstellung einer intraluminalen Endoprothese mit einer biodegradierbaren Hülle. DE102019132938A1, 2021

[12] Oldenburg J, Maletzki L, Strohbach A, Bellé P, Siewert S, Busch R, Felix SB, Schmitz KP, Stiehm M. Methodology for comprehensive cell-level analysis of wound healing experiments using deep learning in MATLAB. BMC Mol Cell Biol. 2021;22(1):32. doi: 10.1186/s12860-021-00369-3

[13] Götz A, Senz V, Schmidt W, Huling J, Grabow N, Illner S, General image fiber tool: A concept for automated evaluation of fiber diameters in SEM images. Measurement. 2021;177:109265. doi: 10.1016/j.measurement.2021.109265

[14] Dohr D, Fiedler N, Schmidt W, Grabow N, Mlynski R, Schraven SP. Frictional Behavior of Cochlear Electrode Array Is Dictated by Insertion Speed and Impacts Insertion Force. Appl Sci. 2021;11(11):5162. doi: 10.3390/app11115162

[15] Helbig C, Wollny A, Altiner A, Diener A, Kohlen J, Ritzke M, Frech S, Guthoff RF. Treatment Complexity in Primary OpenAngle Glaucoma (POAG): Perspectives on Patient Selection in Micro-Invasive Glaucoma Surgery (MIGS) Using Stents. Klin Monbl Augenheilkd. 2021;238(3):302-310. doi: 10.1055/a-1241-4489

[16] Löschner U, Siegosch F, Fleßa S (Editors). Strategien der Implantatentwicklung mit hohem Innovationspotenzial. Von der Idee zur erfolgreichen Standardlösung. Wiesbaden: Springer Gabler; 2021. doi: 10.1007/978-3-658-33474-1 